\title{
Disobeying Marx, Disobeying Derrida-Hopes \& Risks: A Forum on Jacques Derrida's Specters of Marx after 25 Years, Part II
}

\author{
Aggie Hirst* \\ Tom Houseman** \\ Paulo Cesar Duque-Estrada*** \\ Jenny Edkins**** \\ Cristiano Mendes ${ }^{* * * *}$
}

\begin{abstract}
Jacques Derrida delivered the basis of The Specters of Marx: The State of the Debt, the Work of Mourning, \& the New International as a plenary address at the conference 'Whither Marxism?' hosted by the University of California, Riverside, in 1993. The longer book version was published in French the same year and appeared in English and Portuguese the following year. In the decade after the publication of Specters, Derrida's analyses provoked a large critical literature and invited both consternation and celebration by figures such as Antonio Negri, Wendy Brown and Frederic Jameson. This forum seeks to stimulate new reflections on Derrida, deconstruction and Specters of Marx by considering how the futures past announced by the book have fared after an eventful quarter century. In this group of contributions, Aggie Hirst and Tom Houseman, Paulo Cesar Duque-Estrada, Jenny Edkins and Cristiano Mendes reflect on the legacies of Marx and Derrida: on whether Derrida emphasized the wrong Marxian heritage, on the promise and risks of hauntology, on the ghostly potential for justice amidst devastation, and on the paradox of deconstruction's legacy itself.
\end{abstract}

Keywords: Derrida, Jacques; Marx, Karl; hope; futurity; justice; ontology; inheritance.

\footnotetext{
* King’s College London, London, UK; aggie.hirst@kcl.ac.uk. ORCID iD 0000-0002-8111-352X.

** Leeds Beckett University, Leeds, UK; t.s.houseman@leedsbeckett.ac.uk. ORCID iD 0000-0001-8945-7709.

*** Pontifícia Universidade Católica do Rio de Janeiro, Rio de Janeiro-RJ, Brazil; pcde@puc-rio.br. ORCID iD 0000-0001-5066-6933.

**** University of Manchester, Manchester, UK; jenny.edkins@manchester.ac.uk. ORCID iD 0000-0003-14770607 .

***** Pontifícia Universidade Católica de Minas Gerais, Belo Horizonte-MG, Brazil; cristianomendes@gmail. com. ORCID iD 0000-0002-5832-1777.
} 


\section{The Anachronism of Hope: The 'to-come' in Post-horizonal Times}

Aggie Hirst \& Tom Houseman

Amidst the triumphalism of the West after the fall of the Soviet Union, Derrida (1994: 97) contextualised his reading of Marx and Marxism with the statement: '[t]he world is going badly, the picture is bleak, one could say almost black [...] A black picture on a blackboard.' He fleshed out this claim with a list of ten plagues aimed squarely at the self-congratulatory moment encapsulated by Fukuyama's End of History. Deriding the latter as a 'tiresome anachronism,' Derrida (1994: 17) noted that its proponents, seemingly content to 'puff out their chests with the good conscience of capitalism, [and] liberalism', had 'arrived late to the apocalypse.' With an incredulity as pertinent today as it was in 1994, he asked: '[w] hat cynicism of good conscience, what manic disavowal could cause someone to write, if not believe, that "everything that stood in the way of the reciprocal recognition of human dignity, always and everywhere, has been refuted and buried by history"? (Allan Bloom cited in Derrida 1994: 97-98). The central task of Specters of Marx was thus to trace the Marxian inheritances by means of which this bleak era might be navigated, and its evangelical champions challenged. Twenty-five years later, as the world has deteriorated further and liberal triumphalism has given way to anxiety, unrest, and emergency - with even the likes of The Economist asking 'was Marx right?'1 - we might fruitfully look to Derrida with the same intent.

Contemporary readers cannot fail to recognise Derrida's prescience in rehabilitating Marx - or at least Marx's ghosts. But it also appears that Derrida chose the wrong Marx: after the financial crisis, it is the critique of capital - Marx's searing analysis of the capitalist mode of production's tendency towards crisis and failing profitability - that has witnessed a resurgence. Derrida, by contrast, conjures the eschatological Marx of the Communist Manifesto and The German Ideology, who remains out of fashion even amongst Marxists. Yet a closer reading reveals so much that is of urgent and contemporary relevance, if we take the 'specter' to be more than an illustrative motif. Derrida draws extensively on Walter Benjamin's 'Theses on the Philosophy of History' to locate the power of Marx to haunt the present in a transgression; specifically, Marx's use of idealism to (re)animate his historical materialism. As Benjamin (1999: 245) explains, in Marx's thought ' $t$ t] he puppet called "historical materialism" is to win all the time. It can easily be a match for anyone if it enlists the services of theology, which today, as we know, is wizened and has to keep out of sight.' We have discussed this theological inheritance, which Marx acquires through Hegel, elsewhere (Hirst 2013; Houseman 2013; see also Löwith 1949; Taubes 2009). Through his 'hauntology', however, Derrida is able to recognise the grammar of this inheritance as less a question of Judeo-Christian eschatology than Marx's awkward - or maybe even playful - relationship with the actual/ideal binary.

In Specters of Marx, communism acquires its power in the bourgeois present as a persistent irritant that calls into question capitalism's claims to justice and victory, through a contradictory and deeply theatrical temporality, in which communism haunts from the 
future (Derrida 1994: 2-3, 10-21). This 'hauntology', as Benjamin Noys (2012: 27) notes, 'rests in the oddly meta-ontological position of that which pre-emptively ruins the security and primacy of ontology by forcing it to open to the event.' The 'effectivity' of communism, and by extension the eschatological Marx, is for Derrida (1994: 78) dependent on this spectral disorganisation of the temporal order (the 'chain of presents'): 'the logic of the ghost [...] points toward a thinking of the event that necessarily exceeds a binary or dialectical logic that distinguishes or opposes effectivity or actuality (either present, empirical, living - or not) and ideality (regulating or absolute non-presence).' Communism incarnated - so-called 'actually existing communism' - therefore, necessarily forfeits this spectral power. Derrida's exegesis of Marx thus seeks to maintain the suspension of the actual/ideal binary - a suspension that the figure of the specter produces. Doing so allows Derrida (1994: 10) to make sense of the 'irreducible heterogeneity' of Marx's work, and, following Maurice Blanchot, defend it against those who 'in the name of Science or Theory as Science, had attempted to unify or to purify the "good" text of Marx' (Derrida 1994: 10). Marx's enduring power, and our responsibility to our Marxist inheritance, for Derrida, flows from the former's disruptive and subversive transgression of the actual/ideal binary. This transgression can be seen for instance Marx's historiography, in which the free, ideal, self-conscious society is simultaneously a mechanical consequence of a teleological history composed of class antagonism, and at the same time the work of human revolutionary agency (to which he devoted himself to the point of infamy, financial ruin and ill health). This transgression runs through the other Marx, too: his critique of political economy is a materialist account of economic relations, but where commodity fetishism is a necessary explanatory ingredient. For Derrida (1994: 150-155), to close these spectral contradictions, to decide that Marx is an economist or a humanist, a scientist or a philosopher, is to surrender the power of his thought - a risk Marx himself invites, for instance in his critique of Hegel and Stirner.

If Derrida locates Marx's power in the post-Cold War years as flowing from his transgression of the actual/ideal binary, it is because he identifies in that period a fixation with actuality and effectivity. The various discussions in Specters of Marx of Fukuyama's End of History point to this: the claim that the ideal has finally become the actual is really the actual's claim to being ideal. In Derrida's (1994: 78) words, in the triumphalist mode

[o]n the one hand, the gospel of politico-economic liberalism needs the event of the good news that consists in what has putatively actually happened... [H] owever since, on the other hand, actual history and so many other realities that have an empirical appearance contradict this advent of the perfect liberal democracy, one must at the same time pose this perfection as simply a regulating and trans-historical ideal. Depending on how it works to his advantage and serves his thesis, Fukuyama defines liberal democracy here as an actual reality and there as a simple ideal.

Fukuyama's opportunistic deployment of the actual/ideal binary to serve his own rhetorical purposes is, as Derrida notes, clear. However, his framing of the actual as ideal is 
haunted by its manifest untruth, as Derrida set out in his ten 'plagues' (Derrida 1994: 100104), and it is precisely this haunting that animates the mania, anxiety, and darkness that Derrida reads behind the veil of liberal triumphalism. In light of this, in an era in which positivist empiricism, hard-headed business rationality, neoliberal economics, and liberal-democratic institutions proclaimed their objective and proven superiority over other 'contenders', the power of Marx's spectral logic is, for Derrida, activated rather than obviated. Marx's critical materialism, ostensibly 'scientific' anti-idealism, and famous disdain for utopian thinking gives his work a purchase that those easily dismissed as dreamers and fantasists lack. But it is the spectral element in his thought - which smuggles into the realm of actuality something heterogeneous to it: the promise and hope of something different - that offers an antidote to the oppressive actuality of the neoliberal moment.

Returning to Specters of Marx today, though, we must ask if this antidote - the spectral hope of communism, or perhaps simply the specter of hope as such - is adequate to the current poisons. After the 2008 financial crisis, it is no longer counter-intuitive to affirm, as Derrida did in 1994, the potency of Marx, though it is not the spectral or even eschatological Marx who is enjoying a resurgence but rather the materialist prophet of capitalism's tendency towards crisis. Liberal triumphalism has given way to increasing polarisation as electorates around the world abandon business-as-usual centrism in favour of various stripes of nationalism and outright fascism, at the same time as a resurgence and rebranding of socialism is in evidence, even in the United States. Far from being a preserve of philosophy, apocalyptic imaginaries have become a mainstay of Hollywood and small screen alike. This apocalyptic pessimism is presciently prefigured in Specters of Marx. As Antonio Negri commented in 1999, '[ $\mathrm{t}$ ]here's something that's exhausted in these pages, like the shadow of that melancholic libertinism when, at the end of another counter-revolutionary age, men who were still free testified in refusal to the Counter-Reformation and awaited the martyrdom of the Inquisition' (Negri, cited in Noys 2012: 43). In Derrida's (1994: 65) own words, 'never, never in history, has the horizon of the thing whose survival is at stake (namely, all the old models of the capitalist and liberal world) been as dark, threatening, and threatened. Indeed, in this abject epoch, time itself is, according to Derrida (1994: 25), out of joint. He asks: 'what happens when time itself gets "out of joint," dis-jointed, disadjusted, disharmonic, discorded, or unjust? Ana-chronique?'

Despite this apocalyptic thread, however, read today Specters of Marx seems imbued with an insistent, if ethereal, optimism. In spite of, or in response to, the irreducible bleakness of the post-Cold War world, Derrida (1994: 25) asked: 'can one not yearn for a justice that one day, a day belonging no longer to history, a quasi-messianic day, would be finally removed from the fatality of vengeance?' This optimism took the form, as this suggests, of a messianic promise of something different to come. Purged of an arrivant, even of the expectation of an arrivant, Derrida's was a despairing messianism. He explains: 'without this latter despair and if one could count on what is coming, hope would be but the calculation of a program [...] this despairing messianism has a curious taste, a taste of death' (Derrida 1994: 212). Here, as elsewhere, Derrida is clear that such a 'to come' refers not to any actually existing future present, but rather to the structure of faith in a justice always deferred in temporal terms. And yet, this messianism has the structure of a promise, of the horizon. 
This vision leans towards the future, 'deferring not what it affirms but deferring just so as to affirm, to affirm justly, so as to have the power (a power without power) to affirm the coming of the event, its future-to-come itself' (Derrida 1994: 19). In an always-deferred future to come, then, something is affirmed. As this suggests, and as Noys (2012: 30) deftly argues, visible in Specters of Marx is a 'weak affirmationism.' Derrida (1994: 42) explains: it is 'a matter of linking an affirmation (in particular a political one), if there is any, to the experience of the impossible, which can only be a radical experience of the perhaps.' To this extent the messianic, Derrida (1994: 211) claims, 'is always revolutionary. It has to be.' As horizonal hope, the future haunts the present, insisting on the question of "what can be, the eventual disruption and opening of the living present to a future "to come." Hauntology inscribes the imminent necessity of events that will disrupt the "hell of the same" (Baudrillard, cited in Noys 2012: 45).

Indeed, and more concretely, Derrida noted in Specters of Marx that signs of positive change were already in evidence, specifically in the form of a New International. This 'link of affinity, suffering, and hope', he claimed, would involve 'a profound transformation, projected over a long term, of international law, of its concepts, and its field of intervention.' We have, he continued, 'more than one sign of it' (Derrida 1994: 105-6). As Noys (2012: 42) echoes, in 1994 'Derrida insisted, with some justification given the emergence of the alter-globalisation movement, that the "New International" "is already a reality." However, in the current time, that reality, he continues, has 'entered a state of routinisation and seeming decline, which again raises the question of Derrida's tendency to futural invocations of agency' (Noys 2012: 42). This decline - manifest in the current rise of the far right, ecological emergency and the global proliferation of affronts to human and civil rights - forces us to ask whether Derrida's promise of the future-to-come, understood not as a future reality yet to arrive but rather as the structure and possibility of hope itself, has been broken. In a world which feels increasingly horizonless, what place can the 'to come' have? In post-horizonal times, has hope itself become an anachronism?

The idea of the disappearance of a horizon is not new, from Adorno's 1956 claim that 'for the first time we live in a world in which we can no longer imagine a better one' (Adorno and Horkheimer 2011: 108) to the Sex Pistols' 1977 declaration of there being 'No Future.' But within the framework of Specters of Marx, we can trace the specific configuration in which the horizon Derrida articulated no longer quite makes sense. Hope, in the form of Marx's eschatological specter, receives its potency from a moment of idealism smuggled into an otherwise deeply materialist project - the dwarf behind the automaton which aimed to crack open capitalist political economy not from an external moral viewpoint but through a rigorous and immanent critique (Bonefeld 2001). Marx's potency as a challenge to an eternal bourgeois society consists in his agreement with its anti-metaphysical, anti-romantic, anti-utopian self-image. It participates, albeit critically, in positivism's obsession with the actual, the injunction to value-freedom which itself belongs to bourgeois rationality's fixation with the self-interested, calculating individual. Das Kapital is difficult to dismiss as the work of a dreamer. But, as Derrida uncovers, a purely rationalist Marx surrenders that power; Marx's materialism gives him the power to haunt the sterile actuality of the bourgeois present, but it is the moment of idealism - eschatological com- 
munism - that does the haunting. The timeliness of Marx's specters, then, is indexed to the cult of actuality, of materialistic rationality, that characterised bourgeois society. This directs us to paying greater attention to what has changed since the early 1990s; specifically a shift away from actuality as opposed to the ideal, and towards a blurring of the two poles that destabilises and perhaps obviates the subversive power of Marx's transgression and therefore, maybe, even the possibility of spectral haunting that Derrida derives from it.

Spurred especially by the internet, consumer society has shifted in various ways away from the rational transactions of homo oeconomicus. Advertisers increasingly sell lifestyle aspirations in the form of 'content marketing' rather than specific products, while social media has invited the rise and commodification of user-generated content, culminating in the phenomenon of on-brand 'influencers' who make a living through the hybridisation of stealth marketing and social communication. As powerful voices become ever more brazen in their disdain for even the illusion of open and honest rational discourse, with demonstrable hypocrisy seeming no longer a barrier to success (electoral or otherwise), the traditional liberal mechanisms for holding such voices to account are subsumed either drowned out or transformed by - the free flow of misinformation and unverified 'news'. As Derrida (1994: 98) prophetically noted,

[e]lectoral representativity or parliamentary life is not only distorted, as was always the case, by a great number of socio-economic mechanisms, but it is exercised with more and more difficulty in a public space profoundly upset by tele-techno-media apparatuses and by new rhythms of information and communication, by the devices and the speed of forces represented by the latter, but also and consequently by the new modes of appropriation they put to work, by the new structure of the event and of its spectrality that they produce (both invent and bring up to date, inaugurate and reveal, cause to come about and bring up to light at the same time, there where they were already there without being there: it is the relation of the concept of production to the ghost that is in question here). This transformation does not affect only facts but the concept of such 'facts.'

It is emphatically not our intent to lament the loss of a fictional golden age of truth and integrity, but rather to trace the disintegration of the constellation of interrelated binaries that surround and sustain the relationship between the actual and the ideal. It is not hard to perceive a widespread anxiety that everything is now fake, that the actual has become entirely obscured by the simulations and misdirections of a consumer culture growing exponentially more digital by the day. If the spectral power of Marx, of communism to-come, originates in historical materialism's smuggling of the ideal into a social universe otherwise beholden to relentless actuality, then it is plausible that this power has been cancelled and erased by a present in which the architecture of actuality - presence, objectivity, rationality, exchange of equivalents, scientific predictability - makes increasingly less sense. The fugitive and delicate messianic hope that Derrida excavates from 
Marx's specters, which was a powerful antidote to the Fukuyaman moment, may well have lost its purchase.

As appealing as Derrida's vision of the 'to come' may be, it is fundamentally dependent upon the figure of the horizon, of an affective bond with the possibility of something beyond or other than that which is. Read in the current moment, one is struck by the difficulty of conjuring such a horizon. For many, the glimmer which feeds the sense of connection, promise, hope, seems dimmer now than it was when Specters of Marx was published. Framed in terms of differance, one might say that while the differing element holds firm today, the temporal deferring is compromised because the horizon upon which it depends is so blurred by digital consumer culture's bizarre temporality, stuck in a moment of permanent crisis where the constant exhortation to 'follow your dreams' coexists with an apocalyptic sense of imminent and immanent decay. As Noys (2012: 42-4) notes, 'Derrida's tendency to futural invocations of agency', his 'temporal wavering', presupposes a link to the 'to come' which the current political enclosures appear to have blocked. The certain idea of justice in Specters of Marx, differed and deferred, relies on an eschatological or messianic promise that is at present hard to conjure. Without a capacity to hold fast to the promise of the 'to come', the future appears to be qualitatively cancelled, a quantitative lingering in broken time remaining in its stead. Under such conditions, Marx is dead and we have become the specters. Twenty-five years after the publication of Specters of Marx, then, the critical task must be to learn a politics of transformation, resistance, and activation no longer tied to deferrals and promises; a radicalism of and for ghosts.

\section{On History, Ghosts and Ontology}

Paulo Cesar Duque-Estrada

I will go straight to the subject I intend to situate here, that seems to me to be a decisive one in the relation between Derrida's deconstruction and Marxism, which concerns the question of ontology. To this end, I will simply situate a passage from a dialogue between Derrida and Antonio Negri that unfolds around a 'logic of the specter' in Marx, such as perceived by Derrida in Specters of Marx.

Concerning the spectral in Marx, Negri (2008: 6, emphasis added) observes that the specters narrated [by Marx, in German Ideology] have a particular ontological pertinence: they reveal the complete functioning of the law of value.' Moreover, he continues:

A specter is the movement of an abstraction that is materialized and becomes powerful: above all the abstraction of value which, in a bloodless movement, vampirizes all of the worker's labor and, transforming itself into surplus-value, becomes capital; [of] money, 
secondly, which in a circular movement verticalizes itself and is consolidated into currency, i.e., in finance capital and in parasitic potentiality; [of] technology, lastly [...] which, in accumulating itself, in constructing well integrated and firm lines of objective command, regulates and hierarchizes society and life (Negri 2008: 7).

In this perspective, Negri regrets that instead of developing a new ontology which would reveal the new forms of postindustrial capitalist production of wealth, exploitation, subjectivity and reality, Derrida prefers to remain within the spectral logic - something that, for Negri, would be disastrous; an option to remain within the level of 'real illusion' - having as a consequence 'the effect of dramatizing and practically rendering the ontological discovery irrelevant, flattening it onto the obscure background' (Negri 2008: 8).

The practical consequences, in Negri's (2008: 14) assessment, are no less serious:

Through various models of social and linguistic practices, performativity maintains itself in a domain where the sense of belonging to being is left undecidable. And it's with the idea of justice that this knot is entangled, rather than unravels. [...] In fact, when performativity comes to life in practice, when - in its concrete instance - it designates the overcoming of exploitation, exclusion, solitude and misery, it must find its direction in the constitution of being, thereby implicating the question of justice. [...] But it is precisely here [in Derrida's deconstruction] that the knot does not untie [on the contrary, Negri continues], [...] in playing with the specters of being, rather than proposing an exit toward the future, or a new construction of justice that's mingled with new forms of spectral being, [Derrida's deconstruction] turns back and loses itself in that which is 'inaccessible to man', [it loses itself] in the 'infinitely other' [...] Why this regressive step back?

Now, on the part of Derrida, the Heideggerian motif of the 'truth of being' constitutes an important background not only to his engagement with Marx's texts, but also to his reply to Negri. This is, moreover, a key element of the reading or return to Marx proposed by Derrida, and which I would like to bring to light here as my contribution to this present forum dedicated to Specters of Marx. Today, twenty-five years after this book's publication, this subject remains extremely relevant, precisely when one proposes a return of ontologies in the name of a post-deconstructive contemporaneity.

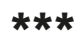

According to Derrida, Heidegger's motif represents an important step towards a conscious resistance against dogmatism; and this insofar as the 'thought of Being,' Derrida underlines, comprises a break with all ontology. As he says, commenting on Heidegger's Letter on Humanism, 'Ontology thinks solely the being of beings or the being in its being' (Derrida 2016: 19). That means, first of all, that ontology turns always to the being of the entity 
[I prefer 'entity' rather than 'being' to translate létant], but never to being as the being of beingness [or 'entitiness', if one could say that; lêtre de l'étantié en general]. In a word, ontology never thinks the truth of Being. This expression supposes an entire trajectory of thought that removes the notion of truth from its classical determination as adequacy of a judicative statement.

What is at stake here, in thinking the truth of being, as Derrida (2016: 20, translation modified) says, is 'a regression to a point not only prior to the entities but even prior to the being of the entities as beingness, towards the truth of being itself.' Therefore, by turning itself to a moment that is prior to the level of entities and their respective modes of being this or that entity - i.e., prior to the authority of their concepts within language - Heidegger's thought on the truth of being demands a break with all conceptual thought. There is no place here for the notion of being, even for the word 'being' itself. That is what the Destruktion of metaphysics is about: a self-destruction of the logos of ontology.

It is in other words a matter of affirming a thought that thinks beyond whatever is assured in the order of discourse; in Heideggerian terms, a thought that thinks beyond what is established and affirmed in the ontic level (i.e., the level of entities or present beings), beyond their genesis, causal relations and conditions of possibility. Thus, beyond the dogmatic paths of scientism, empiricism and humanism; in a word, beyond the domain of calculation. In more Derridean terms, Heidegger opens the possibility of experiencing the abyss underlying every discourse, i.e., the experience of a radical not-knowing that necessarily goes through our discourse about anything. If we could try a formalization here, we could say that the relationship with everything we encounter always unfolds in the light of what has already happened. And this latter, as something that has always and already gone, is never present, never available as such. That is the condition of the radical historicity of things: we are heirs of what has never been present; heirs of ghosts.

That is how the most radical question of the truth of being - as the never present horizon of the relationship with everything we encounter - is intrinsically related with the most radical historicity. According to Derrida, who radicalizes the gesture of Heidegger, the 'experience' of such radical non-knowing is of great importance for a thought - as it is the case of deconstruction and its self-proclaimed proximity with 'a certain spirit of Marxism' - which is driven by an unconditional ideal of emancipation. It is in this perspective that Derrida places a theoretical, philosophical and political responsibility before Marx's texts:

When the dogma machine and the 'Marxist' ideological apparatuses (States, parties, cells, unions, and other places of doctrinal production) are in the process of disappearing, we no longer have any excuse, only alibis, for turning away from this responsibility. There will be no future without this. Not without Marx, no future without Marx, without the memory and the inheritance of Marx: in any case of a certain Marx, of his genius, of at least one of his spirits. For this will be our hypothesis or rather our bias: there is more than one of them, there must be more than one of them (Derrida 1994: 14). 
The reference Derrida makes to the future concerns the future of our being-there, in the world. How to think and act with 'justice,' i.e., 'according to' the way of our being-there - today, in our time - in the world? In this interrogation, a past and a future - two temporal orders which are never present, never given or available as such - are always and necessarily involved. That is the ghostly temporality of history: nothing is present, there is not a 'now' present; neither in the past, nor in the future and not even in the present.

Beyond Heidegger, beyond his distinction between the presence of being and the present being of the entity, thinking and acting with 'justice' - assuming a real responsibility before the fact that things are not the way they should - requires, according to Derrida (1994: 28), an engagement with the structural disjuncture of time:

[the transitional state of the present] has its provenance in what, by essence, has not yet come-from [provenu], still less come about, and which therefore remains to come. The passage of this time of the present comes from the future to go toward the past, toward the going of the gone [l'en allé].

The whole an-economic question of justice in Derrida is given here. Every relation to others has this disjunct temporal structure; a structure of a 'now' that is, in fact, without present:

Beyond right, and still more beyond juridicism, beyond morality, and still more beyond moralism, does not justice as relation to the other suppose [...] the irreducible excess of a disjointure or an anachrony, $[. .$.$] some "out of joint" dislocation in Being and in time$ itself, a disjointure that, in always risking the evil, expropriation and injustice $[. .$.$] against which there is no calculable insurance, would$ alone be able to do justice or to render justice to the other as other? (Derrida 1994: 32).

Outside this an-economic exposition to the other, the alterity of the other is reduced to presence, and so to knowledge, predictability, programming, in a word, to calculation. As Derrida says (1994: 34), justice is then 'reduced once again to juridical-moral rules, norms or representations, within an inevitable totalizing horizon (movement of adequate restitution, expiation or reappropriation).'

That is the core of Derrida's disagreement with Negri:

[Negri] cedes to what I think is the most problematic aspect of Marx, namely, the unrestrained, classical, traditional [...] desire to conjure away any and all spectrality so as to recover the full, concrete reality of the process of genesis hidden behind the specter's mask (Derrida 2008: 258).

And it is the whole problem of scientism, empiricism and even humanism, those forms of dogmatism that, in Derrida's view, start once again to take root in Negri's argument. 
On the basis of what we have previously seen concerning Derrida's reading of Heidegger around the topics of the 'truth of Being' and the break with ontology, it is not difficult to situate what he is talking about, when we read that ontology is always 'carried out with a view of reconstituting, saving, redeeming a full presence of the present-being [in other words, redeeming the being of the entity; l'être de l'étant], where that present-being [...] appears to be lacking [...]' (Derrida 2008: 261).

Thus, to Negri's question in which he regrets Derrida's position - 'why this regressive step back?' (Negri 2008: 14) - it is as if Derrida answered with another question: why insist on the imprisonment of ontological discourse?; why insist on the closure of what is a-historical in essence?; why insist on [present] ontological principles, precisely in the name of history or, better, of emancipatory action? In fact, Derrida (2008: 257) himself asks: 'Why do you want to re-ontologize at all costs, at the risk of restoring everything to order, to the grand order, but to order?'

It is in this way that, regarding the re-ontologization proposed by Negri, Derrida (2008: 260-261, emphasis added) says that it will not 'persuade me to reconsider, [...], the entire deconstruction of the "ontological" motif itself, at its root.'

Of course, the tremor of the a-economic exposure to others always carries a promise for better or for worse, it is never without risks. And yet one has to take risks. Otherwise, there is no responsibility but only calculation, the execution of pre-established programs. And how many crimes were not committed, how many totalitarian or dictatorial practices were not tolerated, precisely according to the execution of emancipatory programs or in the name of a systematic elimination of ghosts? And, thus, Derrida proposes a return to Marx with this precaution, a general precaution he adopts everywhere: 'Sometimes it is necessary to go where thought is exposed to the worst, politically. Otherwise, and this is even worse, the worst comes to add itself to the good conscience' (Derrida 2011: 82-83). 


\section{Ghost stories}

The philosophers have only interpreted the world, in various ways. The point, however, is to change it.

- Karl Marx, Eleven Theses on Feuerbach

Read his work, and the earth moves; it's not just the new way of thinking, nor the words that weave their magic, but the feeling of being seen.

Striding the Salford streets with his cotton-spinning-mill-owner friend, does he pass by my wage-slave ancestors in the back-to-backs of Weaste?

When the wall falls and his followers are welcomed with weasel words, does his corpse in Highgate right itself to wander the world once more?

Does it help an Algerian exile dislodge the philosophers' stone, show the West the work of its wanton ways, and open a future-to-come?

Show that what we shut out returns to decentre our sureness, haunting our very existence, hollowing out from within?

The Moor roams Salford no more; its houses are bulldozed, its ships stilled, dockers and packers gone to their graves in a waste land of concrete and glass.

Thirty years on from Berlin, what reckoning with Specters of Marx? What á venir when new walls are built, and profit gives birth to extinction?

When accepting impossibility does not condone or exempt, what excuse for avoiding the struggle to conjure, not concepts, but justice? 


\section{$\star \star *$}

Karl Marx would travel from his home in London to visit his friend and collaborator Friedrich Engels in the industrial city of Salford, Greater Manchester. The cotton mill Engels' family owned in Weaste, a working-class district of Salford, stood a stone's throw from Bridson Street, where my grandfather's family lived. The M602 motorway now runs through both sites, and the docks have been redeveloped as Salford Quays. Marx, nicknamed 'The Moor', is buried in Highgate Cemetery in North London. Jacques Derrida, author of Specters of Marx, was born in Algeria, and the book was written in the aftermath of the fall of the Berlin Wall in 1989, when Marxists were no longer seen as dangerous but offered tea and sympathy.

\section{(In) Derrida's Shadow}

Cristiano Mendes

\section{Expectancy}

In the fourth and final part of Thus Spoke Zarathustra, Nietzsche (1992) proposes describing the Übermensch, a being yet to manifest who shall surpass the human species. Suspecting that it is not possible to name someone yet to come, for the very qualification of being would nullify that being's condition as novel, Nietzsche prefers to say what is not part of the Übermensch, thus creating an outline of posthumous man through his negations, that is by describing what he is not.

According to Nietzsche, the Übermensch is one who does not adopt negative nihilism; does not agree with the government of the plebs; does not find in positivist science its source of truths; does not surrender to Apollonian art; does not bow to religious temptation; does not separate the aesthetic from the rational; does not reproduce the philosophy of charlatans; and, mainly, does not cast a shadow. During his walk, Zarathustra finds all these negations in their metaphorical forms, and when he realises the need to deconstruct them, he invites them to a banquet in which he will not partake. Among those dining, the figure found at the end of the row of guests receives special attention. As the final negation of the Übermensch, the Shadow, tired of accompanying the hermit all his life, grows weary and heartbroken. Not having created its own paths, the Shadow is said to be lost, adrift with its destiny. Zarathustra invites the Shadow to supper in his cave while awaiting the arrival of the Übermensch. 


\section{The Shadow}

The shadow metaphor pervades Western narratives as an illustration of the role of adherents and apprentices. To live in someone's shadow means being condemned to follow a certain person by assuming their form and at the same time being credited only as a mere mockery of an original idea. The disciple's role rests on the reproduction of a recognised matrix, being original only in its ramifications of something primordial, like a shadow in relation to its owner; inheritors of a wealth of thought in which originality happens only by extension, re-readings or complements.

The presence ${ }^{2}$ of Derrida in post-structuralist narratives offers us an aporetic inheritance of the apprentice and his own legacy. The practice of adherence is undue because it incapacitates novelty in a radical way; adherence to schools of thought becomes something artificial and arbitrary. The effect of adherence to an authorial tradition thus becomes improper and undue in the sense of contradicting the very notion of displacement and contingency presented by Derrida. ${ }^{3}$

However, like Schlemihl, who sold his shadow to the devil, and was therefore excluded from society, authors are judged by the shadows they produce in certain traditions, or by the adherents who accompany them in the course of their work. Without shadows, an author is not noticed, and no tradition is built. An author without followers finds himself in the condition of a stateless intellectual whose legacy is lost in the absence of reproduction. The disciple, in turn, gains by being recognised as heir to a tradition of thought but loses by surrendering to its reproduction. The authority of the legacy makes it one of the key pieces in the game of reproduction. Being an adept of someone's thought defines one's scope while limiting one's thinking.

However, like every legatee, one must accept responsibility over one's inheritance and move on in such a way as to conjure the specter of one's preceptor in order to guarantee his or her presence even in the absence of the original. But like every specter, the image of the original author in the works of his followers happens in an ethereal way, a déjà vu produced by repetitions that maintain the existence of a tradition while denying a primordial originality in its reproduction: the responsibility of keeping in mind the foundational myth and the eternal return; the obligation to belong to a past arbitrarily defined in the present; and the responsibility to revive at any moment the phantom of a supposed primary authorship. Derrida (1994: 124) writes, 'There is no inheritance without a call to responsibility. An inheritance is always the reaffirmation of a debt, but a critical, selective, and filtering reaffirmation, which is why we distinguish several spirits.

\section{The Inheritance}

When in the shadow of a matrix, the disciple presents himself or herself as lacking in content and his or her countenance only produces something innovative as a simulacrum of a predecessor or tradition. Linked to disciples' performances are the limitations imposed by not being able to absolutely deny their membership under the risk of declining their referential tutelage. Their condition, therefore, reflects a contradiction in which every disciple 
resembles the mentor, while at the same time never being confused with that mentor: a simulacrum in which the preceptor must and, at the same time, must not be present. The apprentice as a shadow becomes equal to and at the same time different from a model. For such a model, denying one's paternal figure is impossible, and at the same time, one is prohibited from totally distancing oneself from the father. The search for influences, mentors, or inheritance reveals, therefore, the assumption of authorship as entailing origination. The founding moment of an original thought entails conception by and credited to a certain author responsible for the thought's origination. Inheritance as shadow or sham. A disciple denies the myth of his or her father's death and, as a shadow, reproduces in his or her own way the inherited tradition.

For Derrida, every inheritance presupposes mourning. All reproduction indicates the death and continuation of the parent. The specter of an author, like every specter, simultaneously indicates the presence and absence of the being that originated it. 'An inheritance is never given, it is always a task. It remains before us as incontestably as the fact that, before even wanting it or refusing it, we are inheritors, and inheritors in mourning, like all inheritors' (Derrida 1994: 78).

A central problem, however, challenges us: how can one consider oneself to be the heir to an author who teaches us to deny the role of authorship?

\section{The Logocentrism}

One of the deconstructive strategies mobilised by Derrida (2005a) presupposes the inversion of the traditional logic of the relationship between the author and his/her work. Conservatively, an author is considered as an autonomous and sovereign entity. An author is credited ownership of his or her ideas only insofar as the author can go beyond his/ her own tradition, producing something considered innovative. The author's work thus becomes a source that, despite being possessed of texts prior to its own production, can at least present itself as original in the primordial sense of the term.

However, this idea of an original author, who produces works under his own name, depends on logocentric presuppositions. First, there is the consideration that the author is a being that thinks for him/herself. The author is the owner of a sovereign intellect and, therefore, is capable of being credited as an originator. Second, there is the assumption that the works produced by an author have in their nature something primal, a mark of affiliation that legitimates, in an incontestable way, their creator's interpretation of the truth supposedly contained in his/her texts. When in doubt as to what the author truly meant, he or she is guaranteed the final word on the matter.

By denying logocentrism, Derrida disengages from the very possibility of inheritance. If rather than the author being the creator of a work, the opposite is true, how can we say that an authorial tradition exists? Without an authorial tradition, legacy becomes contextual by making texts out to be mere products of other texts and not of their writers.

The negation of authorship, therefore, makes impossible any foundational moment of a thought and requires the inevitable inference that this same negation may also have no authorship. By positing that written works are not the product of their authors, Derrida 
becomes a victim of the very perspective that relativizes authorship, leading us to deny also any authority a writer may have over the very texts that bear his or her name. This brings us to a radical relativization of textual interpretations in which a hierarchy of versions of a text cannot be defined by objective criteria. Textual translations are thus at the mercy of the legitimations granted by audiences and are not judged from the criteria of metaphysical truths authenticated by the supposed author. The scholia of a text become part of this, though no longer as accessories, because it is no longer possible to unveil the supposed truths hidden in the original, but, as an addition to it in a polyphonic production of non-hierarchical meanings in the absence of an absolute reference.

Searching for traces of Derrida in post-structuralist narratives tells us more about Derrida than about his inheritance. The search for shadows reveals the specter of its predecessors while reducing the traces of disciples to posthumous footprints in a hereditary logic.

\section{The Traditions}

One of the consequences of the impossibility of authorship is the artificiality of the divisions of theoretical approaches. It would only be possible to say that a certain author joins a tradition of thought if this tradition were constructed in a natural and progressive way. Thus, the so-called realist authors would be indebted to Thucydides, Machiavelli, Hobbes, Clausewitz and Carl Schmitt. The so-called post-structuralists would be heirs of the sophists and of Nietzsche, Derrida and Foucault. However, since the deconstruction of logocentrism requires the impossibility of authorship, every tradition comes to be seen as an a posteriori construction, through movements that would arbitrarily highlight the similarities and, at the same time, ignore the differences between these authors and their contexts (Walker 1995). Traditions would thus be relativized by perspectivism in a logic according to which any author can be allocated in any tradition of thought, depending on the highlighted elements and the ignored characteristics. Therefore, we can infer that any classification of authors as post-structuralists can be made only outside this supposed tradition. An author who claims to be post-structuralist in an objective way, by ignoring the arbitrariness of the tradition that marks belonging to it, would be immediately disqualified from the classification.

The presence of the Sophists in Stirner; of Stirner in Nietzsche; of Nietzsche in Derrida; of Derrida in post-structuralism: ghosts feeding into a desire for fatherhood and sonhood without which any tradition would be infeasible. The fetish of organising authors into ideational scaffolds reinforces the idea of a linear and cumulative time. This idea of the foundational moment precludes novelty in its most radical sense. The reference to remnants of a current of thought makes any originality impossible in its absolute form. In a self-referential movement, traditions become the boundaries of the authors at the same time as the authors are curtailed by the traditions to which they refer. If Nietzsche chose to describe the Übermensch solely in terms of what he is not, it was because he knew that modernity precludes the new. Nietzsche's 'Beyond-Human', antipode of Fukuyama's (1995) 'Last Man', would only have its singularity guaranteed by the non-adjectivisation of 
it. Any attempt to describe the Übermensch would already mean a prelude to his presence and, consequently, his ultimate non-belonging to originality. The disciples who reproduce and bring texts to life in posterity of their predecessors are the same ones that render unfeasible the unpublished its inexorable form.

There is the negation of the possibility of descendants, even though these exist and insist on pointing out their paternal lineage. This impossibility of heredity, however, generates an aporia. The exaltation made by the supposed preceptor to his adherents of not following his path ends up becoming a paradox. Obedience to this command means being faithful and, at the same time, denying the preceptor's request. A non-linear reasoning in which there is no way out of the antinomy, the contradiction rests in the paternal figure teaching his descendants not to imitate him; in doing so, they may end up disobeying him. As in the conversation of Timon and Alcibiades, cited by Derrida in Specters of Marx, the aporia of obedience becomes inevitable:

Promise me friendship but perform none. If thou wilt promise, the gods plague thee, for thou art a man. If thou dost not perform, confound thee, for thou art a man (Derrida 1994: 66).

From this perspective, doubt about 'being or not being' ceases to be a matter of questioning and instead becomes a condition for the presence of disciples. Because they are faithful to their father, these disciples, who end up disobeying their father as they renounce fatherhood, also become disciples because of their obedience. The absence of the shadow, or its presence in the absolute sense, becomes a sine qua non for what has yet to come.

It was midday when the Übermensch arrived.

\section{Notes}

1 [Editors' note] See the video, "Was Marx Right?" posted by The Economist on 4 May 2018: https://www. youtube.com/watch?v=TMmDebW_OBI

2 [Note by Mendes] Presence here, not in the sense of immanence or tradition, but rather as a trace and otherness (Derrida 2005a).

3 [Note by Mendes] According to Derrida (2004), all reality is fluid, and nothing repeats itself in absolute terms. In this way, belonging to a tradition means believing in the possibility of repetition by ignoring the inevitable ephemerality of being.

\section{References}

Adorno, T W and M Horkheimer. 2011. Towards a New Manifesto. Transl. Rodney Livingstone. London: Verso.

Benjamin, W. 1999. Illuminations. London: Random House.

Bonefeld, W. 2001. 'Kapital and its Subtitle: A note on the meaning of critique.' Capital \& Class 75: 53-63.

Chamisso, A. 2003. A História Maravilhosa de Peter Schlemihl. São Paulo: Ed. Estação Liberdade. 
Derrida, J. 1994. Specters of Marx: The State of the Debt, the Work of Mourning, \& the New International. Transl. Peggy Kamuf. New York: Routledge.

1994. Espectros de Marx: o estado da dívida, o trabalho do luto e a nova internacional. Rio de Janeiro: Ed. Relume Dumará.

2001. Posições. Belo Horizonte: Ed. Autêntica.

2004. Gramatologia. São Paulo: Ed. Perspectiva.

2005a. A Escritura e a Diferença. São Paulo: Ed. Perspectiva.

2005b. A Farmácia de Platão. São Paulo: Ed. Iluminuras.

2005c. A Voz e o Fenômeno. Lisboa: Ed. 70.

2008. 'Marx \& Sons.' In Michael Sprinker (ed), Ghostly Demarcations: A Symposium on

Jacques Derrida's Specters of Marx. New York: Verso, pp. 213-269.

2011. Politique et l'amitié: Entretiens avec Michael Sprinker sur Marx et Althusser. Paris: Galilée.

2016. Heidegger: The Question of Being \& History. Transl. Geoffrey Bennington. Chicago: The University of Chicago Press.

Fukuyama, F. 1995. O Fim da História e o Último Homem. Rio de Janeiro: Ed. Rocco.

Hirst, A. 2013. 'Violence, Self-authorship and the 'Death of God': The 'Traps' of the Messianic and the Tragic.' Millennium: Journal of International Studies 42 (1): 135-154.

Houseman, T. 2013. 'Auschwitz as Eschaton: Adorno's Negative Rewriting of the Messianic in Critical Theory'. Millennium: Journal of International Studies 42 (1): 155-176.

Löwith, K. 1949. Meaning in History: The Theological Implications of the Philosophy of History. Chicago: University of Chicago Press.

Negri, Antonio. 2008. 'The Specter's Smile.' In Michael Sprinker (ed), Ghostly Demarcations: A Symposium on Jacques Derrida's Specters of Marx. New York: Verso, pp 5-16

Nietzsche, F. 1984. Crepúsculo dos Ídolos: ou a Filosofia a Golpes de Martelo. São Paulo: Ed. Hemus. 1992. Assim Falava Zaratustra. São Paulo: Ed. Hemus.

1992. Além do Bem e do Mal: prelúdio a uma filosofia do futuro. SP: Companhia das Letras.

Noys, B. 2012. The Persistence of the Negative: A Critique of Contemporary Continental Theory. Edinburgh: Edinburgh University Press.

Taubes, J. 2009. Occidental Eschatology. Stanford: Stanford University Press.

Walker, R. B. J. 1995. Inside/Outside: international relations as political theory. Cambridge: Cambridge University Press.

\section{About the authors}

Aggie Hirst is Lecturer in International Relations Theory and Methods in the Department of War Studies at King's College London. Her research is situated in critical IR/ political theory, with a focus on violence, resistance and play. She is currently writing a book titled 'The Politics of Play: Wargaming with the US Military', which explores the use 
of immersive games to teach and train service members. She is author of Leo Strauss and the Invasion of Iraq: Encountering the Abyss (Routledge 2013) and several journal articles exploring the thought of Jacques Derrida and Friedrich Nietzsche.

Tom Houseman is Senior Lecturer in Politics and International Relations, Leeds Beckett University, UK. His work and teaching explores critical theory, the politics of knowledge, coloniality and international development. He completed his Ph.D., using Adorno to interrogate prevailing concepts of poverty, at the University of Manchester in 2011. Since then, Tom has taught at a number of UK Universities and recently contributed to the SAGE Handbook of Frankfurt School Critical Theory. He also plays guitar with Manchester-based hardcore band Follow Your Dreams.

Paulo Cesar Duque-Estrada is Professor of Philosophy at Catholic University of Rio de Janeiro (PUC-Rio). He works in the fields of phenomenology, hermeneutics and deconstruction. He has been teaching as well as publishing articles and presenting papers at conferences in Brazil and abroad on topics regarding deconstruction. He is presently working on topics related to subjectivity, sacrifice, law, "écriture", reference, veracity, critique of ontology and politics.

Jenny Edkins is Professor of Politics at The University of Manchester. Her most recent monograph is Change and the Politics of Certainty (Manchester University Press, 2019). She is editor of the Routledge Handbook of Critical International Relations (2019) and co-editor of After Grenfell: Violence, Resistance and Response (Pluto Press, 2019) and the third edition of Global Politics: A New Introduction (Routledge, 2019). She has been exploring narrative and performance as research practices for a number of years, and is currently working on a poetry collection. A recent poem, 'As it turned out', appears in Planet: The Welsh Internationalist, Autumn 2019, to mark the thirtieth anniversary of the fall of the Berlin Wall.

Cristiano Mendes is Professor of International Relations at the Department of International Relations, of the Pontifical Catholic University of Minas Gerais. He holds a Ph.D. in International Relations from University of Brasília (UnB) and a Masters in Political Science from the Federal University of Minas Gerais, Brazil. Professor Mendes is the author of articles and book chapters about terrorism, failed states and private military and security companies. He was a visiting professor at the University of Sydney, Australia (2011), and a visiting researcher at the University of Coimbra, Portugal (2014). Professor Mendes's area of research focuses on security studies and post-positivist theories of international relations. 


\title{
Desobedecendo Marx, Desobedecendo Derrida- Esperanças e Riscos: Um Fórum sobre os Espectros de Marx de Jacques Derrida depois de 25 Anos, Parte II
}

\begin{abstract}
Resumo: Jacques Derrida entregou a base de os Espectros de Marx: O Estado da Dívida, a Obra do Luto e a Nova Internacional como discurso plenário na conferência 'Para onde o marxismo?', na Universidade da Califórnia, em Riverside, em 1993. A versão mais longa do livro foi publicada em francês no mesmo ano e em inglês e português no ano seguinte. Uma década após a publicação dos Espectros, as análises de Derrida provocaram uma grande literatura crítica e convidaram tanto a consternação quanto a celebração de figuras como Antonio Negri, Wendy Brown e Frederic Jameson. Este fórum procura estimular novas reflexões sobre Derrida, desconstrução e Espectros de Marx, considerando como futuro do passado anunciado pelo livro se saiu depois de um movimentado quarto de século. Nesse grupo de contribuições, Aggie Hirst e Tom Houseman, Paulo César Duque-Estrada, Jenny Edkins e Cristiano Mendes refletem sobre os legados de Marx e Derrida: se Derrida enfatizava a herança marxista errada, a promessa e os riscos da hauntologia, o potencial fantasmagórico da justiça em meio à devastação e o paradoxo do próprio legado da desconstrução.
\end{abstract}

Palavras-chave: Derrida, Jacques; Marx, Karl; esperança; futuridade; justiça; ontologia; herança.

Received on 8 July 2019, and approved for publication on 26 July 2019. 


\section{ERRATUM}

On article 'Disobeying Marx, Disobeying Derrida-Hopes \& Risks: A Forum on Jacques Derrida's Specters of Marx after 25 Years, Part II', with DOI number 10.1590/ s0102-8529.2019410300008, published on Contexto Internacional, 41(3): 643-662, on cover page in article thematic:

Where it reads:

ARTICLES

Should read:

FORUM: JACQUES DERRIDA'S SPECTERS OF MARX AFTER 25 YEARS 